Article

\title{
On Temperature Dependence of Microstructure, Deformation Mechanisms and Tensile Properties in Austenitic Cr-Mn Steel with Ultrahigh Interstitial Content $\mathrm{C}+\mathrm{N}=1.9$ Mass. $\%$
}

\author{
Elena Astafurova *(D), Sergey Astafurov $(\mathbb{D}$, Galina Maier, Irina Tumbusova, Eugene Melnikov, \\ Valentina Moskvina, Marina Panchenko, Kseniya Reunova and Nina Galchenko \\ Institute of Strength Physics and Materials Science SB RAS, 2/4 Akademicheskii ave., 634055 Tomsk, Russia; \\ svastafurov@gmail.com (S.A.); galinazg@yandex.ru (G.M.); tumbusova031098@mail.ru (I.T.); \\ melnickow-jenya@yandex.ru (E.M.); valya_moskvina@mail.ru (V.M.); panchenko.marina4@gmail.com (M.P.); \\ reunova.ksenya@mail.ru (K.R.); galchenko_nikon04@mail.ru (N.G.) \\ * Correspondence: elena.g.astafurova@gmail.com; Tel.: +7-903-913-23-39
}

Received: 22 May 2020; Accepted: 10 June 2020; Published: 13 June 2020

\begin{abstract}
The microstructure, deformation mechanisms, tensile properties and fracture micromechanisms of ultrahigh-interstitial austenitic Fe-22Cr-26Mn-1.3V-0.7C-1.2N (mass.\%) steel were investigated in wide temperature interval. After conventional homogenization and solid-solution treatment, the steel possesses complex hardening which includes grain boundary, solid-solution and dispersion strengthening. In the temperature interval of -60 to $+60^{\circ} \mathrm{C}$, steel demonstrates striking temperature dependence of a yield strength which could be enhanced by the increase in solid-solution treatment temperature. The variation in test temperature does not change the dominating deformation mechanism of the steel, dislocation slip and insufficiently influences tensile elongation and fracture micromechanisms. The insignificant increase in the fraction of brittle cleavage-like component on the fracture surfaces of the specimens in low-temperature deformation regime is promoted by increase in planarity of dislocation arrangement and the gaining activity of mechanical twinning. In high-temperature range $\left(200-300^{\circ} \mathrm{C}\right)$ of deformation, a negative strain-rate dependence, serrations on the stress-strain diagrams and improved strain-hardening associated with a dynamic strain aging phenomenon have been observed.
\end{abstract}

Keywords: high-interstitial steel; austenite; twinning; strain aging; dispersion strengthening; solid-solution strengthening; grain boundary strengthening; fracture

\section{Introduction}

The modern industry requires the design of new high-strength and ductile materials or the development of novel technologies for improvement of the operational characteristics in conventional materials. The widespread commercial application of austenitic stainless steels (SS) is associated with the attractive combination of mechanical and technological characteristics in them [1,2]. Insufficient values of strength characteristics and wear resistance are the main disadvantages of the conventional austenitic SSs [1,2]. The problem could be solved by reducing the grain size of the steels via thermal-mechanical processing [3-7] but this approach needs to use the time- and energy-consuming technologies such as severe plastic deformation and heat treatments. Another problem arises from the need to use the expensive and environmentally unfriendly nickel as one of the main alloying elements for improvement of corrosion resistance and austenite stabilization in commercial austenitic steels [1,2]. 
Both above-mentioned problems could be solved by alloying of steel with nitrogen which is the strong austenite stabilizer [8,9]. The development of high-nitrogen steels (HNS) in the middle of the 20th century has allowed to design the high-strength materials with a superior corrosion resistance but without significant loss of ductility and toughness [8-12]. For nitrogen-alloyed steels, the striking temperature dependence of a yield strength is peculiar. Their strength properties increase with decrease in test temperature much stronger than those in interstitial-free materials [8,13-15]. Therefore, HNSs could be effectively used in wide temperature range including reduced and even cryogenic temperatures. The problem limiting the commercial use of HNSs as materials for cryogenic applications is that they demonstrate a ductile-to-brittle transition (DBT) in low-temperature deformation regime [8,16-18]. The characteristic temperature of DBT is dependent on nitrogen content. For high-nitrogen steels with $\mathrm{C}_{\mathrm{N}}=0.8-1.0$ mass. $\%$, low ductility and fracture toughness are observed at rather high temperatures which are only several tens degrees below room temperature $[8,19]$. Brittle cleavage-like fracture and the phenomenon of DBT are not typical for $f c c$ alloys. In austenitic nitrogen-bearing steels these effects are closely related to nucleation and growth of the brittle cracks along \{111\}-type crystallographic planes (or close to them). This peculiarity arises due to intersection of dislocations (or twins) with boundaries of mechanical twins in conjugative systems $[16,20]$ or $\gamma-\alpha^{\prime}$ phase transformation $[21,22]$ in steels with low stacking fault energy (SFE). In steels with high SFE-values, it occurs by slipping-off of active slip planes assisted by planar dislocation slip [17]. That is, the change in the value of SFE (either via decreasing in test temperature or alloying) defines the beginning of mechanical twinning and governs phase transformations $[23,24]$. But the variation of the SFE could not be applied directly for suppression of the low-temperature brittleness in HNSs because nitrogen-alloying forces the planarity of deformation-assisted dislocation arrangement in austenite [25]. Grain refinement could be also used for decreasing in DBT temperature similar to that in bcc alloys [26] but its efficiency for N-bearing steels calls questions in research works by B. Hwang et al. [21] and A. Akbari and R. Mohammedzadeh [27].

Mentioned above problems of HNSs could be solved using the physical concept for combined alloying of the austenitic steels with nitrogen and carbon $(C+N)[13,28,29]$. Using this concept, the high-strength wear-resistant $\mathrm{CrMnCN}$ steels have been designed, which are characterized by the relatively high ductility and reduced DBT-temperature in reference to nitrogen-bearing steels [28,30]. Later, using the approach of $(\mathrm{C}+\mathrm{N})$-alloying, a series of new steels was designed, for instance, Fe-18Cr-18Mn-0.85(C + N) steel with wear characteristics comparable to Hadfield steel [31], Fe-14Cr-16Mn-0.3C-0.3N steel with significantly larger yield strength and stronger sensitivity to the test temperature than in conventional Fe-Mn-(Al)-C TWIP steels [32] or Fe-22Mn-0.6C-0.1N steel with suppressed plastic instability [33]. In accordance with the experimental and theoretical data of V. Gavriljuk with coauthors, good combination of strength and ductility of high-interstitial steels (HIS) is associated with the increase in the concentration of free electrons in austenite due to combined alloying with nitrogen and carbon, as compared to alloying with only one of these elements [13,28-30]. This is related to the different effects in $(\mathrm{C}+\mathrm{N})$-alloyed steels which need a further elaboration-nitrogen-assisted suppression of a dynamic strain aging and increase in short-range ordering in carbon-bearing steels [33], different solid-solution hardening effects of nitrogen and carbon and different austenite stability in C- and $\mathrm{N}$-alloyed austenite $[21,34]$ and others. The substitution of the part of nitrogen by carbon atoms in HISs is the effective way to decrease the DBT temperature relative to $\mathrm{N}$-alloying to the same concentrations but the tendency to increase a DBT-temperature with growth in common $(\mathrm{C}+\mathrm{N})$ concentration is also exist [28].

One more way to avoid or partially suppress the DBT assumes the inhibition of a planar dislocation arrangement in HISs with high SFE by means of coarse non-deformable particles. Such coarse inclusions change stress-distribution in the structure under loading and activate dislocation sources in the systems with non-maximal Schmidt factors. This mechanism was proposed for low-temperature deformation regime of vanadium-alloyed Fe-Cr-Mn-N,C and Fe-Cr-Mn-Ni-N,C steels in our recent research [35]. Alloying of HNSs with $1.5 \%$ vanadium increases strength and ductility of these steels due to formation of fine-grained structure and precipitation hardening with $\mathrm{VN}$ and $\mathrm{V}(\mathrm{C}, \mathrm{N})$ phases [35-38]. Moreover, 
vanadium increases the solubility of nitrogen in steels [9] and ultrahigh-interstitial CrMn steels with the concentrations of $\mathrm{C}+\mathrm{N}=1.2$ mass.\% and $\mathrm{C}+\mathrm{N}=1.9$ mass.\% have been previously designed [39]. Nevertheless, there is still a lack of experimental data on the complex influence of two factors (solid-solution hardening due to $\mathrm{C}+\mathrm{N}$ alloying and precipitation hardening due to alloying with vanadium) on the temperature dependence of the strength properties and fracture mechanisms, particularly for ultrahigh interstitial content $(\mathrm{C}+\mathrm{N}>1$ mass.\%).

This study aimed to reveal the complex influence of $\mathrm{C}+\mathrm{N}$ solid-solution hardening and vanadium-based particle strengthening on mechanical properties, microstructure and fracture micromechanisms of ultrahigh-interstitial steel (UHIS) with $\mathrm{C}+\mathrm{N}>1$ mass.\% in the range of testing temperatures from -60 to $300{ }^{\circ} \mathrm{C}$.

\section{Materials and Methods}

Austenitic vanadium-containing Fe-22Cr-26Mn-1.3V-0.2Ni-0.7C-1.2N (mass.\%) steel with ultrahigh interstitial content $(\mathrm{C}+\mathrm{N}=1.9$ mass. $\%, \mathrm{C} / \mathrm{N}=0.58)$ was considered in the paper. For ultrahigh interstitial content $(\mathrm{C}+\mathrm{N})>1$ mass. $\%$, the $\mathrm{C} / \mathrm{N}$ in the interval $0.5-0.6$ is favorable for austenite stability as compared to higher C/N-ratio [28,30]. Therefore, this C/N-ratio was assumed for design of the steel. Vanadium content was chosen on the basis of our previous study [36]. The initial 5-kg steel billet was produced by induction melting and casting in air atmosphere using standard laboratory equipment. Cast steel bars were initially hot-rolled at temperature of $1050^{\circ} \mathrm{C}$ and cooled in air. The chemical composition of the steel was initially measured using HG-Profiler 2 (Horiba, Kyoto, Japan) spectrometers and ONH 836 (LECO Corporation, St. Joseph, MI, USA) and was further controlled by energy dispersive X-ray spectrometry (EDS) (INCA, Oxford Instruments, Abingdon, UK) during transmission electron microscopical (TEM) and scanning electron microscopical (SEM) analyses.

Flat dumbbell-shaped specimens for uniaxial tensile mechanical tests were cut from the hot-rolled bars and then solution treated with final water-quenching. Thermal treatments were carried out in an inert gas atmosphere. After mechanical grinding, an electrolytic polishing of the tensile specimens was carried out using a supersaturated solution of a chromium anhydride $\left(\mathrm{CrO}_{3}\right)$ in a phosphoric acid $\left(\mathrm{H}_{3} \mathrm{PO}_{4}\right)$. The resultant gauge sections of the tensile specimens were equal to $16.0 \mathrm{~mm} \times 3.0 \mathrm{~mm} \times 1.25 \mathrm{~mm}$. Static uniaxial tension tests were carried out using a universal testing machine LFM-125 (Walter + Bai AG, Löhningen, Switzerland) equipped with high-temperature chamber and low-temperature bath.

Specimens for study the temperature dependence of tensile properties and fracture micromechanisms were subjected to 1 -h solid-solution treatment (SST) at different temperatures $\left(\mathrm{T}_{\mathrm{SST}}\right)-1100{ }^{\circ} \mathrm{C}, 1200{ }^{\circ} \mathrm{C}$ and $1230^{\circ} \mathrm{C}$ with a subsequent quenching into water of room temperature. According to our previous research, these SSTs provide different ratios of solid-solution, grain boundary and dispersion hardening components [39]. These specimens were tested in the temperature range $\left(\mathrm{T}_{\mathrm{MT}}\right.$-the temperature of the mechanical test) from -60 to $+60^{\circ} \mathrm{C}$ with the initial strain rate of $5 \times 10^{-4} \mathrm{~s}^{-1}$. At least five specimens were tensile tested until fracture for each test temperature to calculate the averaged values of the mechanical properties (the yield strength and elongation) and their standard error. For calculation of the yield strength, the additional values were included into statistics, which were obtained from the plastic flow diagrams corresponded to the specimens tested for microscopical study (three to five specimens at each test temperature).

For strain aging experiments, specimens were subjected to 1-h SST at the temperature $1200{ }^{\circ} \mathrm{C}$ following by the water-quenching. This treatment was chosen to avoid grain boundary precipitates at the preservation of the high solid-solution component. The effects of test temperature on a strain-rate sensitivity and strain-hardening rate in the steel were determined by strain rate variation at a base strain rate of $1 \times 10^{-4} \mathrm{~s}^{-1}$ and in the temperature range from room temperature up to $300{ }^{\circ} \mathrm{C}$. Flow stress increments $\Delta \sigma$ were measured in the plastic flow regime by a momentary change in strain rate from $1 \times 10^{-4} \mathrm{~s}^{-1}$ to $1 \times 10^{-3} \mathrm{~s}^{-1}$ at $2 \%$ of plastic strain (to eliminate the effect of the variation of the gauge length of the specimen on strain rate). The stresses were calculated for the steady-state regimes of 
plastic deformation at both strain-rates to avoid any artefacts due to machine displacement during the strain rate jump). Three specimens were tested for each test temperature.

The X-ray diffraction (XRD) analysis was done using a DRON 3 diffractometer with $\mathrm{Cu}-\mathrm{K} \alpha$ radiation. Characteristic microstructure of the specimens was evaluated by TEM-study using a JEOL JEM-2100 (Tokyo Boeki Ltd., Tokyo, Japan) electron microscope operated at an accelerating voltage of $200 \mathrm{kV}$. Additionally to the conventional selected area electron diffraction (SAED) analysis and TEM bright-field and dark-field methods, the scanning TEM (STEM) regime was used for characterization of the deformation microstructure. Stacking fault energy (SFE) of the steels was measured by the width of extended threefold dislocation nodes [40]. To characterize the SFE, steel specimens were deformed at RT to $5 \%$ plastic strain. At least ten symmetrical nodes were measured for each SST regime. The fracture surfaces of the specimens were studied after tensile test to failure using the conventional scanning electron microscopy methods (VEGA 3 Tescan, Brno, Czech Republic).

\section{Results}

\subsection{The Effect of Deformation Temperature in The Interval from $-60^{\circ} \mathrm{C}$ to $+60^{\circ} \mathrm{C}$ on Microstructure, Deformation Mechanisms and Tensile Properties in Cr-Mn UHIS}

Regardless of the SST temperature, the steel possesses austenitic structure with numerous coarse precipitates. The increase in $\mathrm{T}_{\mathrm{SST}}$ is accompanied with the increase in solid-solution component (increase in austenite lattice parameter), decrease in volume fraction of the particles and grain growth (Table 1). The distributions of the particles in austenitic matrix in specimens treated at different $\mathrm{T}_{\mathrm{SST}}$ are shown in Figure 1. The Cr-based and V-based phases (hcp- $\mathrm{Me}_{2} \mathrm{X}$ and fcc-MeX) are peculiar for the SST at $1100{ }^{\circ} \mathrm{C}$ and $1200{ }^{\circ} \mathrm{C}$. These particles are homogeneously distributed in the austenitic matrix (Figure 1a,b, Table 1). For specimens treated at $\mathrm{T}_{\mathrm{SST}}=1230^{\circ} \mathrm{C}$, the fcc- $-\mathrm{Me}_{23} \mathrm{C}_{6}$ and V-based fcc-MeX phases are identified. In contrast to the lower $\mathrm{T}_{\mathrm{SST}}$, the grain boundary precipitates are observed in the specimens treated at $\mathrm{T}_{\mathrm{SST}}=1230^{\circ} \mathrm{C}$ (Figure 1c, Table 1). They are morphologically similar to discontinuous decomposition cells typical for high-nitrogen austenite steels in age-hardening. The effect of SST on phase composition and structural parameters was described in detail in our previous research [39]. These data are summarized in Table 1.

Table 1. The influence of solid-solution temperature on phase composition and parameters of the structure in ultrahigh-interstitial steel (UHIS).

\begin{tabular}{cccc}
\hline \multirow{2}{*}{ Parameter } & \multicolumn{3}{c}{ Solid-Solution Temperature } \\
\cline { 2 - 4 } & $\mathbf{1 1 0 0}{ }^{\circ} \mathbf{C}$ & $\mathbf{1 2 0 0}{ }^{\circ} \mathbf{C}$ & $\mathbf{1 2 3 0}^{\circ} \mathbf{C}$ \\
\hline Phase composition & $\begin{array}{c}\text { Austenite, } \mathrm{Me}_{2} \mathrm{X}(\mathrm{hcp}), \\
\mathrm{MeX}(\mathrm{fcc})\end{array}$ & $\begin{array}{c}\text { Austenite, } \mathrm{Me}_{2} \mathrm{X}(\mathrm{hcp}), \\
\mathrm{MeX}(\mathrm{fcc})\end{array}$ & $\begin{array}{c}\text { Austenite, } \mathrm{MeX}_{(\mathrm{fcc}), \mathrm{Me}_{23} \mathrm{C}_{6}} \\
(\mathrm{fcc}), \mathrm{Me}_{23} \mathrm{C}_{6}{ }^{*}(\mathrm{fcc})\end{array}$ \\
\hline Austenite lattice parameter, $\AA$ & 3.6373 & 3.6486 & 3.6535 \\
\hline Austenite grain size, $\mu \mathrm{m}$ & $7.0 \pm 2.1$ & $10.4 \pm 5.2$ & $15.0 \pm 7.5$ \\
\hline $\begin{array}{c}\text { Particle mean size/volume } \\
\text { fraction, } \mu \mathrm{m} / \%\end{array}$ & $670 / 9.0$ & $570 / 6.5$ & $750 / 4.1$ \\
\hline $\begin{array}{c}\text { Concentration of } \mathrm{Cr} / \mathrm{Mn} / \mathrm{V} \\
\text { in austenite }\end{array}$ & $18-19 / 26 / 0.4-0.5$ & $19-20 / 25-26 / 0.5-0.6$ & $21-22 / 25-26 / 0.9-1.0$ \\
\hline $\begin{array}{c}\text { Stacking fault energy of } \\
\text { austenite, } \mathrm{mJ} / \mathrm{m}^{2} \text { (TEM) }\end{array}$ & $45 \pm 3$ & $51 \pm 13$ & $25 \pm 3$ \\
\hline
\end{tabular}

${ }^{*}$ grain boundary precipitates.

Figures 2-4 show temperature dependencies of the mechanical properties in UHIS treated at different SST temperatures. Plastic deformation of the steel develops in one stage with high strain-hardening coefficient $\theta=\mathrm{d} \sigma / \mathrm{d} \varepsilon$ which is slightly dependent on $\mathrm{T}_{\mathrm{MT}}$ in the temperature interval -60 to $+60{ }^{\circ} \mathrm{C}$ (Figure 2c,f,i). More noticeable differences in deformation behavior are seen when one compares the strain-hardening behavior for the specimens treated at different $\mathrm{T}_{\mathrm{SST}}$ at constant values 
of $\mathrm{T}_{\mathrm{MT}}$ (Figure 3). Two main tendencies are obvious for deformation of the specimens with increase in $\mathrm{T}_{\mathrm{SST}}$. The first one is associated with the change in plastic flow behavior from parabolic shape to the linear one with more pronounced transition stage between elastic and plastic deformation regimes. The second one-with the decrease in strain-hardening rate notedly in low-temperature deformation regime (Figure 3).
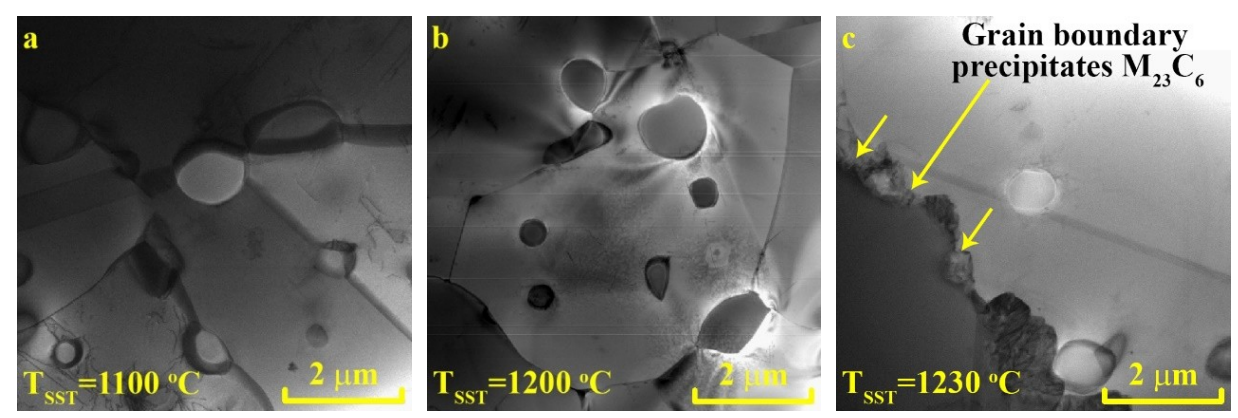

Figure 1. Characteristic scanning transmission electron microscopy (STEM) images of the microstructure in UHIS depending on solid-solution temperature: $(\mathbf{a}) \mathrm{T}_{\mathrm{SST}}=1100^{\circ} \mathrm{C} ;(\mathbf{b}) \mathrm{T}_{\mathrm{SST}}=1200^{\circ} \mathrm{C} ;(\mathbf{c}) \mathrm{T}_{\mathrm{SST}}=1230^{\circ} \mathrm{C}$.
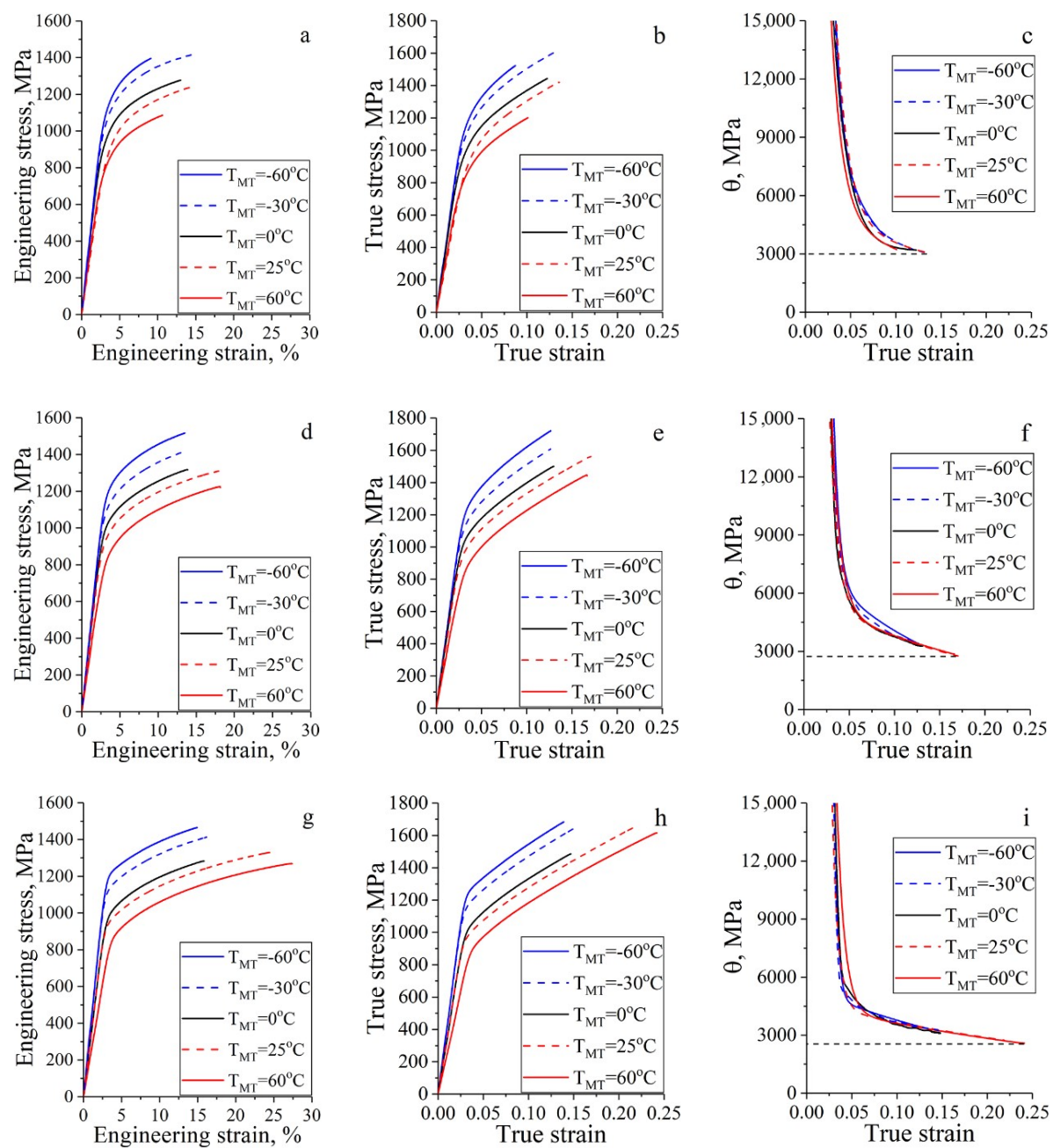

Figure 2. The influence of solid-solution treatment (SST) and mechanical testing (MT) temperatures on mechanical properties of ultrahigh-interstitial steel: $(\mathbf{a}, \mathbf{d}, \mathbf{g})$ engineering stress-engineering strain diagrams; (b,e,h) true stress-true strain diagrams; (c,f,i) strain-hardening coefficient vs. true strain: $(\mathbf{a}, \mathbf{b}, \mathbf{c}) \mathrm{T}_{\mathrm{SST}}=1100{ }^{\circ} \mathrm{C} ;(\mathbf{d}, \mathbf{e}, \mathbf{f}) \mathrm{T}_{\mathrm{SST}}=1200^{\circ} \mathrm{C} ;(\mathbf{g}, \mathbf{h}, \mathbf{i}) \mathrm{T}_{\mathrm{SST}}=1230^{\circ} \mathrm{C}$. 

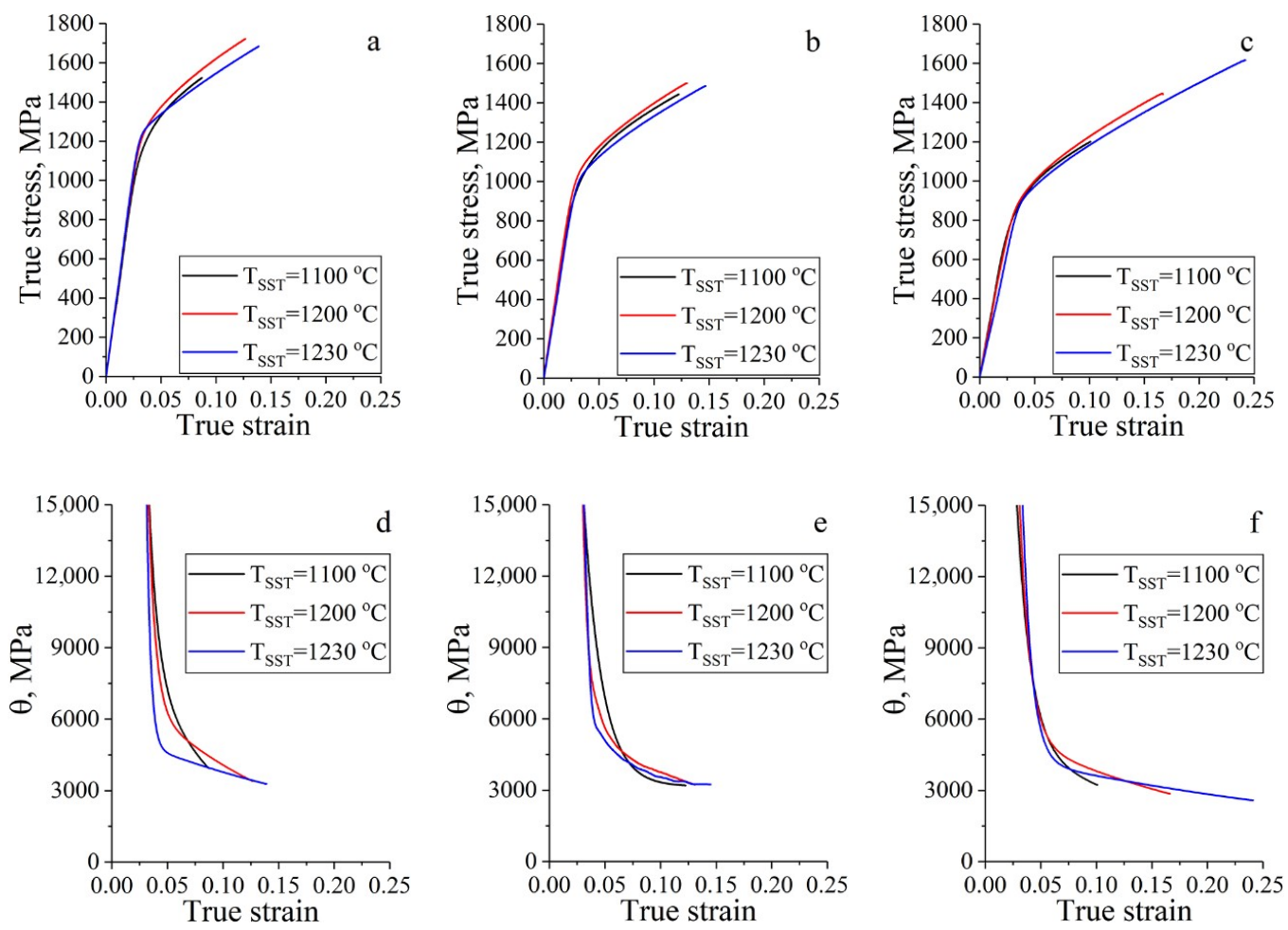

Figure 3. The influence of SST and MT temperatures on true stress-true strain diagrams $(\mathbf{a}, \mathbf{b}, \mathbf{c})$ and strain-hardening coefficient $(\theta)$ vs. true strain $(\mathbf{d}, \mathbf{e}, \mathbf{f}):(\mathbf{a}, \mathbf{d}) \mathrm{T}_{\mathrm{MT}}=-60{ }^{\circ} \mathrm{C} ;(\mathbf{b}, \mathbf{e}) \mathrm{T}_{\mathrm{MT}}=0{ }^{\circ} \mathrm{C}$; $(\mathbf{c}, \mathbf{f}) \mathrm{T}_{\mathrm{MT}}=+60^{\circ} \mathrm{C}$.
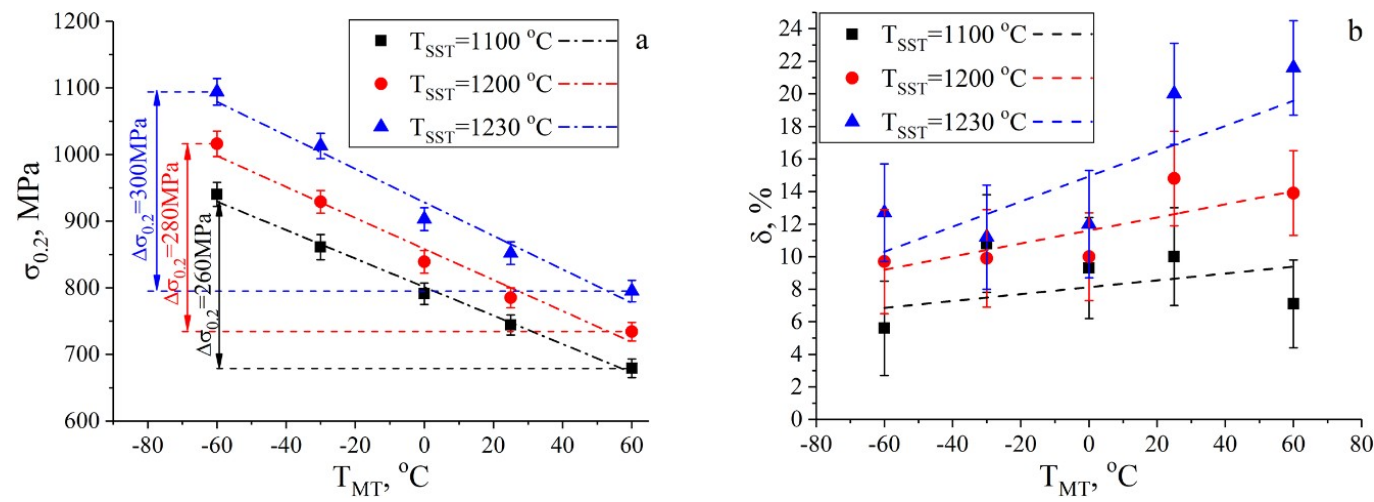

Figure 4. Temperature dependencies of mechanical properties of UHIS for different SST temperatures: (a) yield strength; (b) elongation to failure. Dash lines in (b) show averaged trends of temperature dependencies.

Independently on the SST regime, steel possesses striking temperature dependence of the yield strength $\left(\sigma_{0.2}\right)$ and the higher $\mathrm{T}_{\mathrm{SST}}$ the higher $\sigma_{0.2}$-values (Figure $\left.4 \mathrm{a}\right)$. Increase in both SST temperature and test temperature have the positive effect on the elongation to failure ( $\delta$ ) of the steel (Figure $4 \mathrm{~b}$ ). In the given temperature range -60 to $+60^{\circ} \mathrm{C}$ there is no pronounced low-temperature embrittlement of the steel by "inability to sufficient plastic deformation" criterion.

Figures 5-7 demonstrate typical deformation microstructures of the steel treated at different $\mathrm{T}_{\mathrm{SST}}$ and tensile tested to $5 \%$ strain at $\mathrm{RT}$ and $\mathrm{T}_{\mathrm{MT}}=-60^{\circ} \mathrm{C}$. The planar dislocation arrangement is peculiar for all $\mathrm{T}_{\mathrm{MT}}$ and $\mathrm{T}_{\mathrm{SST}}$-dislocation pile-ups are clearly seen in STEM and bright-field TEM images. Both factors, lower test temperature and higher SST temperature, assist planar slip. In room-temperature tests, dislocation slip is the basic deformation mechanism of the steel at low strains. Despite planar 
dislocation arrangement, rather homogeneous distribution of dislocations is seen in TEM images corresponded to $\mathrm{T}_{\mathrm{SST}}=1100^{\circ} \mathrm{C}$ (Figure 5a,b). Instead, powerful pile-ups with hundreds of perfect dislocations in each, single stacking faults and splitted dislocations, high dense dislocation walls are observed in specimens treated at $\mathrm{T}_{\mathrm{SST}}=1200{ }^{\circ} \mathrm{C}$ and $\mathrm{T}_{\mathrm{SST}}=1230{ }^{\circ} \mathrm{C}$ (Figures $6 \mathrm{a}$ and $\left.7 \mathrm{a}, \mathrm{b}\right)$.
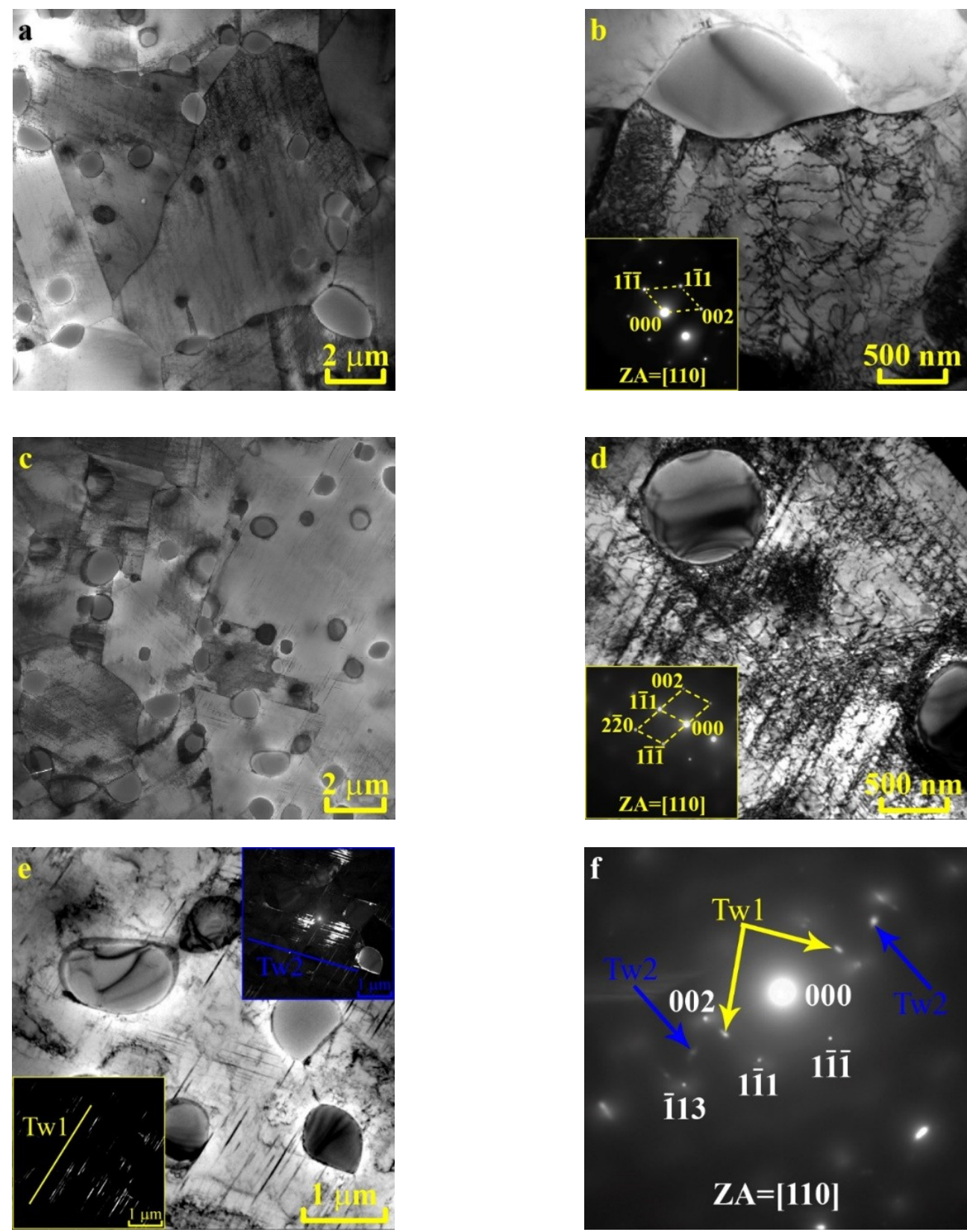

Figure 5. Typical TEM images of microstructure of UHIS after $5 \%$ strain at room temperature $(\mathbf{a}, \mathbf{b})$ and $-60{ }^{\circ} \mathrm{C}(\mathbf{c}-\mathbf{f}), \mathrm{T}_{\mathrm{SST}}=1100{ }^{\circ} \mathrm{C}$. Selected area electron diffraction (SAED) pattern probe area for figures (b,d,f) is $1.4 \mu \mathrm{m}^{2}$. Twin reflections (Tw1 and Tw2) and traces of twinning planes (Tw1 and Tw2) are shown in figures $(\mathbf{f}, \mathbf{e})$, respectively. 

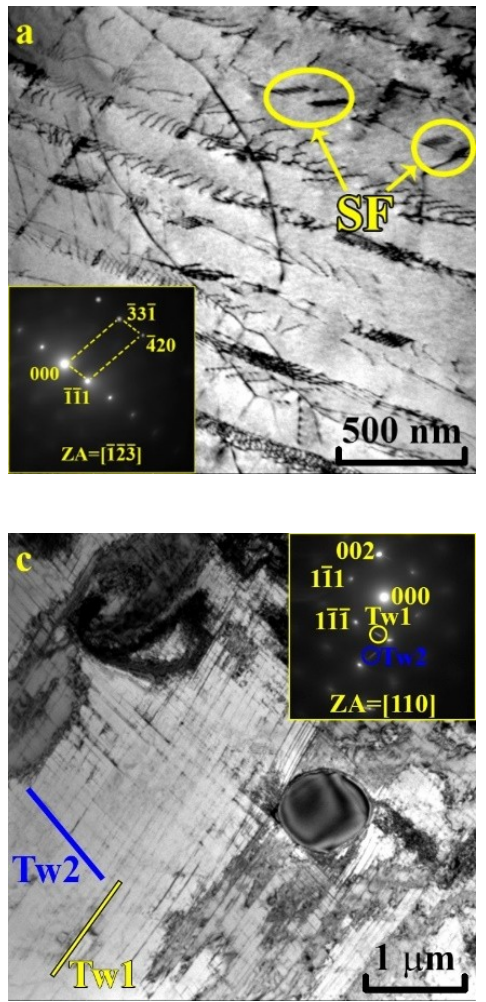
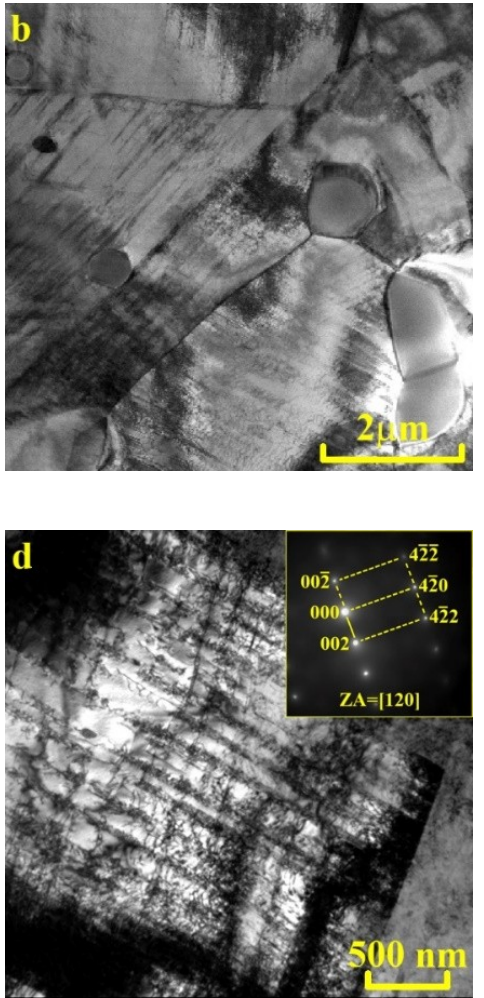

Figure 6. Characteristic microstructure in UHIS after $5 \%$ strain at room temperature $(\mathbf{a})$ and $-60{ }^{\circ} \mathrm{C}(\mathbf{b}-\mathbf{d})$, $\mathrm{T}_{\mathrm{SST}}=1200^{\circ} \mathrm{C}$. SAED pattern probe area for figures $(\mathbf{a}, \mathbf{c}, \mathbf{d})$ is $1.4 \mu \mathrm{m}^{2}$. Twin reflections are marked as Tw in (c, insert). SF-stacking faults.
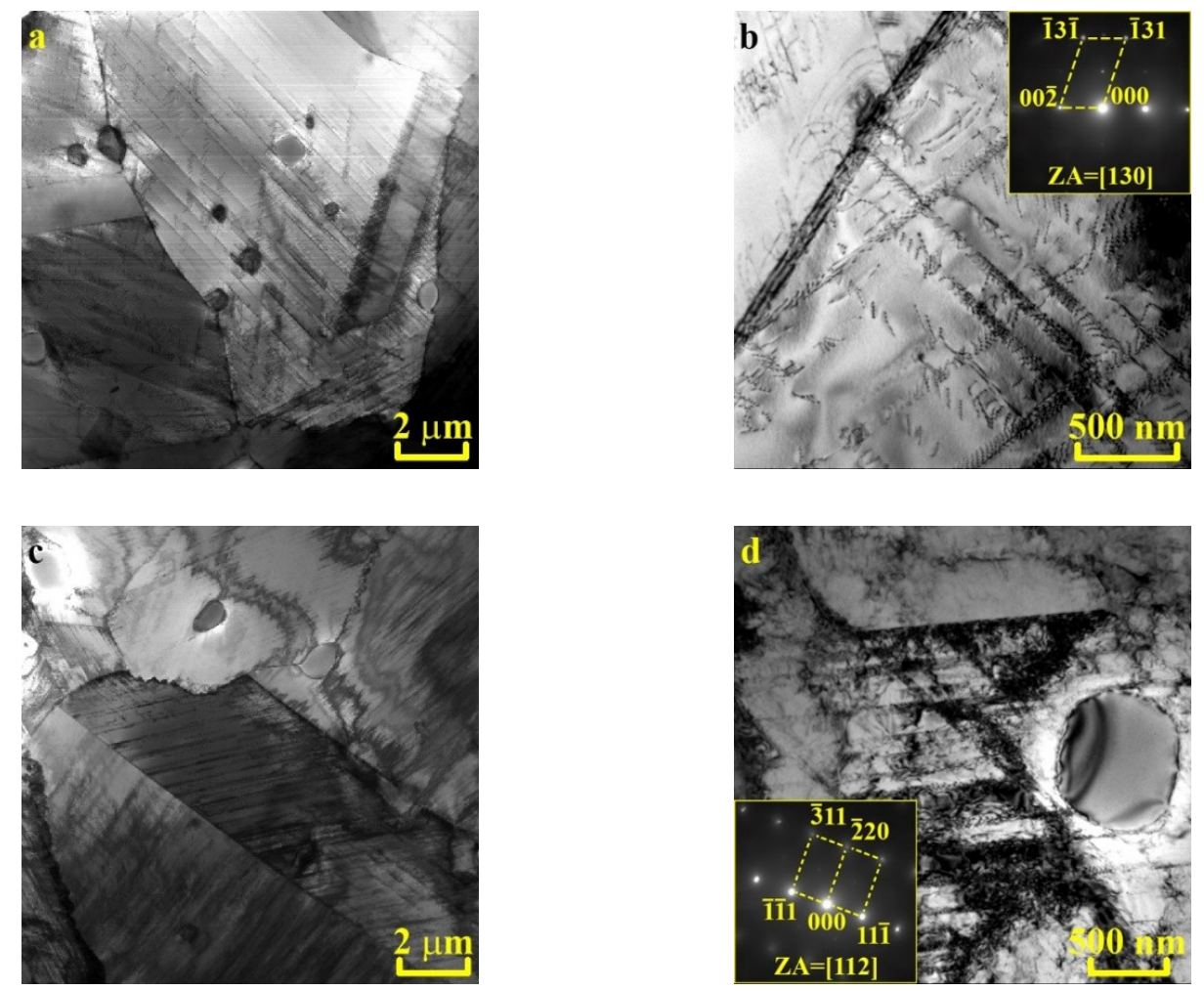

Figure 7. Cont. 

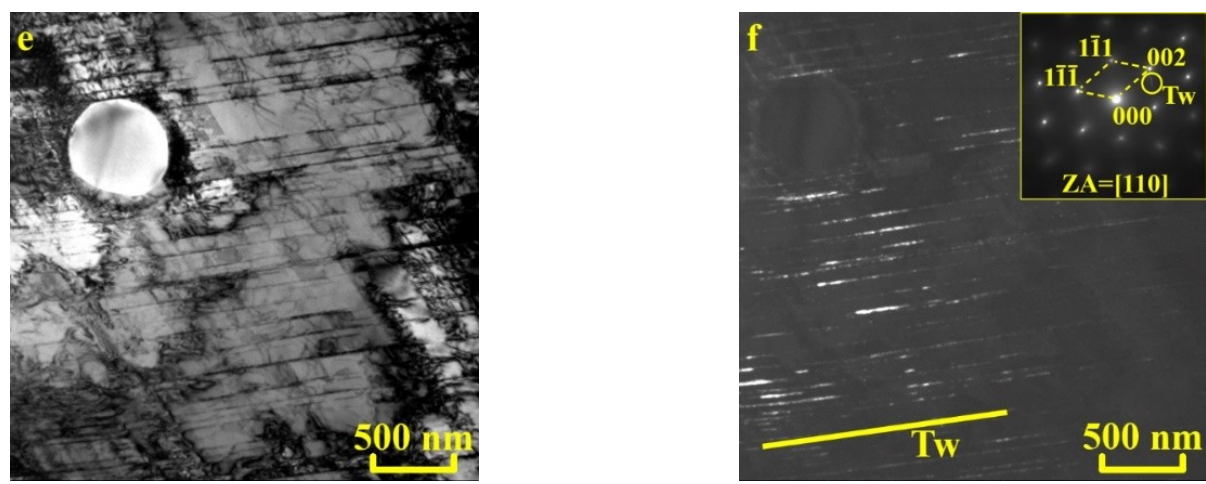

Figure 7. Typical TEM images of microstructure of UHIS after $5 \%$ strain at room temperature $(\mathbf{a}, \mathbf{b})$ and $-60{ }^{\circ} \mathrm{C}(\mathbf{c}-\mathbf{f}), \mathrm{T}_{\mathrm{SST}}=1230{ }^{\circ} \mathrm{C}$. SAED pattern probe area for figures $(\mathbf{b}, \mathbf{d}, \mathbf{f})$ is $1.4 \mu \mathrm{m}^{2}$. Twin reflection is marked as Tw in (f, insert).

In low-temperature tests, at $\mathrm{T}_{\mathrm{MT}}=-60{ }^{\circ} \mathrm{C}$, the similar dependence in dislocation arrangements on $\mathrm{T}_{\mathrm{SST}}$ is observed even though the planarity of the microstructure becomes stronger in comparison with room-temperature deformation (Figure $5 c, d$, Figure $6 b, d$ and Figure $7 c, d)$. Independently on SST temperature, a mechanical twinning is observed in some grains and the appearance of this deformation mechanism becomes more frequent with an increase in $\mathrm{T}_{\mathrm{SST}}$ (Figure 5e,f, Figures $6 \mathrm{c}$ and 7e,f).

\subsection{Fracture Micromechanisms in the Temperature Range from $-60{ }^{\circ} \mathrm{C}$ to $+60^{\circ} \mathrm{C}$}

Independently on SST and test temperature, there is no stage associated with a macroscopic localization and neck formation in engineering stress-strain diagrams (Figure 2a,d,g). The specimens have failed abruptly. Nevertheless, their fracture cannot be interpreted as brittle from the point of view a macroscopical deformation because specimens undergo several percent of plastic deformation prior to failure. Typical SEM images of the fracture surfaces in the UHIS are shown in Figure 8 for different SST and deformation temperatures. All fracture surfaces demonstrate the prevailing dimple morphology typical for a ductile fracture.

For specimens treated at $\mathrm{T}_{\mathrm{SST}}=1100{ }^{\circ} \mathrm{C}$ and $\mathrm{T}_{\mathrm{SST}}=1200{ }^{\circ} \mathrm{C}$, a transgranular fracture mode with the dimple morphology is peculiar (Figure 8a-d). The low fraction of the cleavage-like component has also been detected which corresponds to brittle failure of the individual austenitic grains (as example, marked in yellow circles on the Figure $8 \mathrm{a}, \mathrm{b}$ ). For the $\mathrm{T}_{\mathrm{SST}}=1230^{\circ} \mathrm{C}$ regime, providing the formation of grain boundary precipitates, the complex intergranular and transgranular failure mode is realized (Figure 8e,f). Shallow dimples are seen on the surfaces of intergranular components. They correspond to the destruction along grain boundaries-in austenite depleted by interstitial atoms by neighboring $\mathrm{Me}_{23} \mathrm{C}_{6}$ particles. Transgranular components show both coarse dimples and cleavages. But the fraction of the brittle cleavage-like regions is higher than that in specimens treated at lower temperatures (Figure 8a,c,e). For each chosen SST regime, the dominating fracture micromechanism of the specimens does not change in the given temperature range but the contribution of the brittle cleavage-like component gradually increases with the decrease in test temperature (Figure 8). 

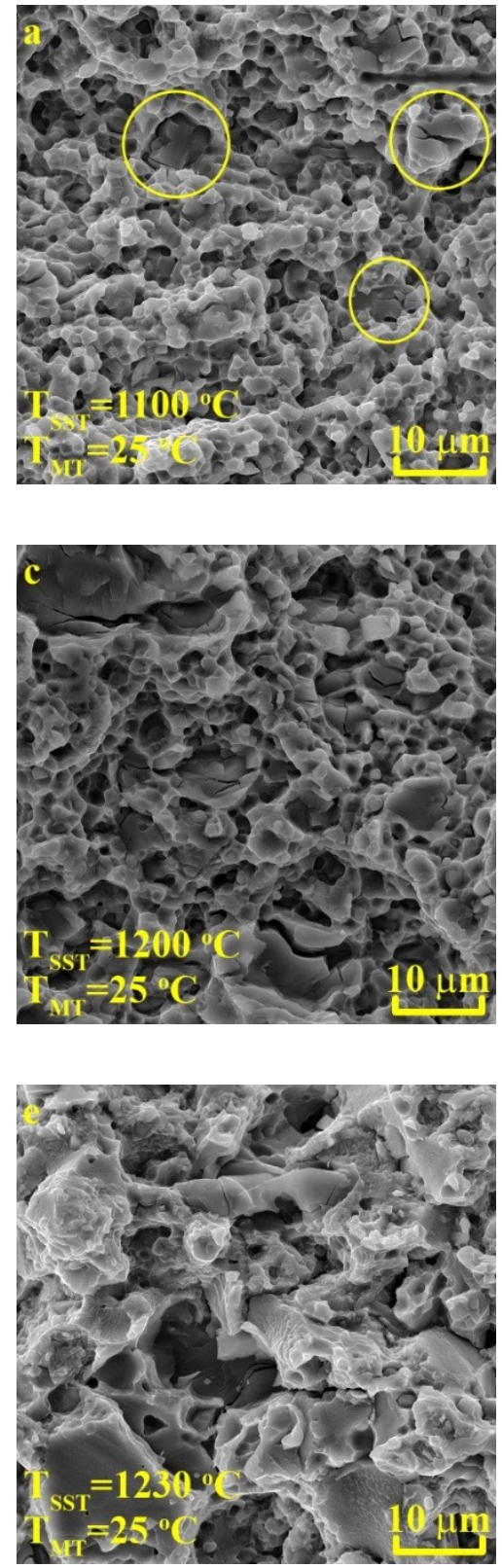
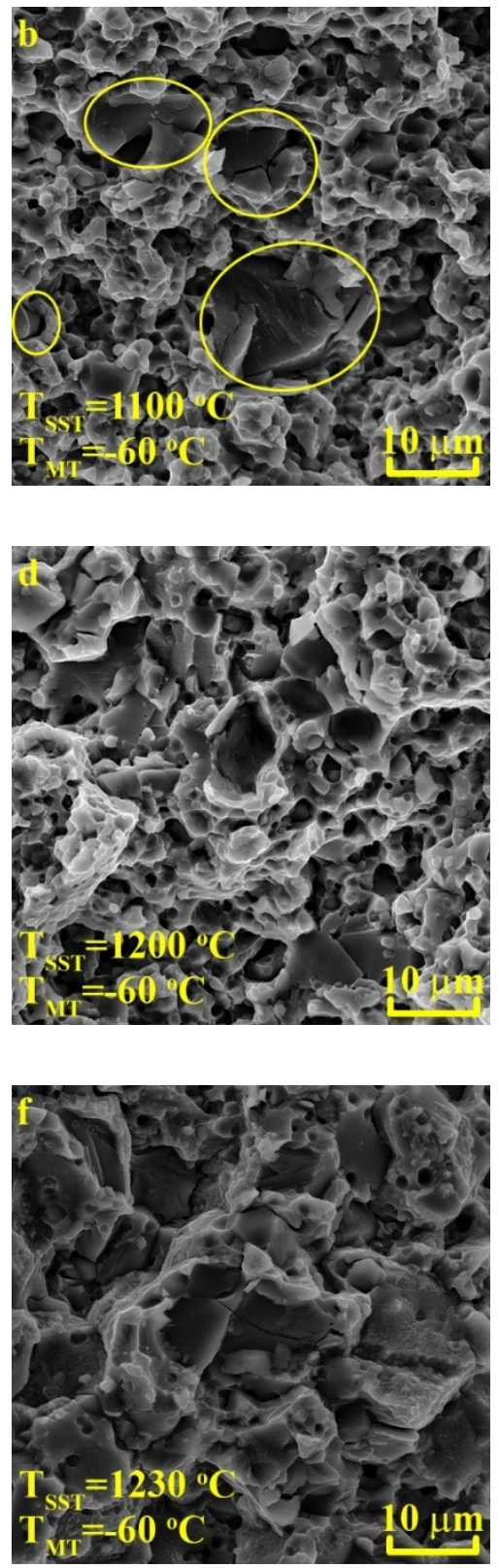

Figure 8. Typical SEM images of the fracture surfaces in specimens of UHIS after tensile testing at room temperature $(\mathbf{a}, \mathbf{c}, \mathbf{e})$ and $-60{ }^{\circ} \mathrm{C}(\mathbf{b}, \mathbf{d}, \mathbf{f}):(\mathbf{a}, \mathbf{b}) \mathrm{T}_{\mathrm{SST}}=1100^{\circ} \mathrm{C} ;(\mathbf{c}, \mathbf{d}) \mathrm{T}_{\mathrm{SST}}=1200{ }^{\circ} \mathrm{C} ;(\mathbf{e}, \mathbf{f}) \mathrm{T}_{\mathrm{SST}}=1230{ }^{\circ} \mathrm{C}$. Brittle components are marked by circles on the images $(\mathbf{a}, \mathbf{b})$.

\subsection{The Dynamic Strain Aging Phenomenon in the UHIS Solution Treated at $1200^{\circ} \mathrm{C}$}

The typical "true stress-true strain" diagrams for the temperature interval from RT up to $300{ }^{\circ} \mathrm{C}$, the temperature dependence of the yield strength, strain-hardening and strain-rate sensitivity $\Delta \sigma / \Delta \ln (\dot{\varepsilon})$ of the steel are presented in Figure 9. In Figure 9c,d, the temperature limits of the dynamic strain aging (DSA), serrated flow (SF) and negative strain-rate dependence (NSRD) are shown. The visible increase in $\sigma_{0.2}$-values, the stress increment $\left(\sigma_{i}-\sigma_{0.2}\right)$ for $\mathrm{i}=2 \%$ and $\mathrm{i}=4 \%$ of the plastic strain, jagged (jerky or serrated) flow and negative (or close to zero) strain-rate sensitivity are peculiar for the DSA-phenomenon and they are observed in UHIS in the temperature interval $200-300^{\circ} \mathrm{C}$ (Figure 9a-d). A type of serrations is the temperature-dependent characteristic as well. 

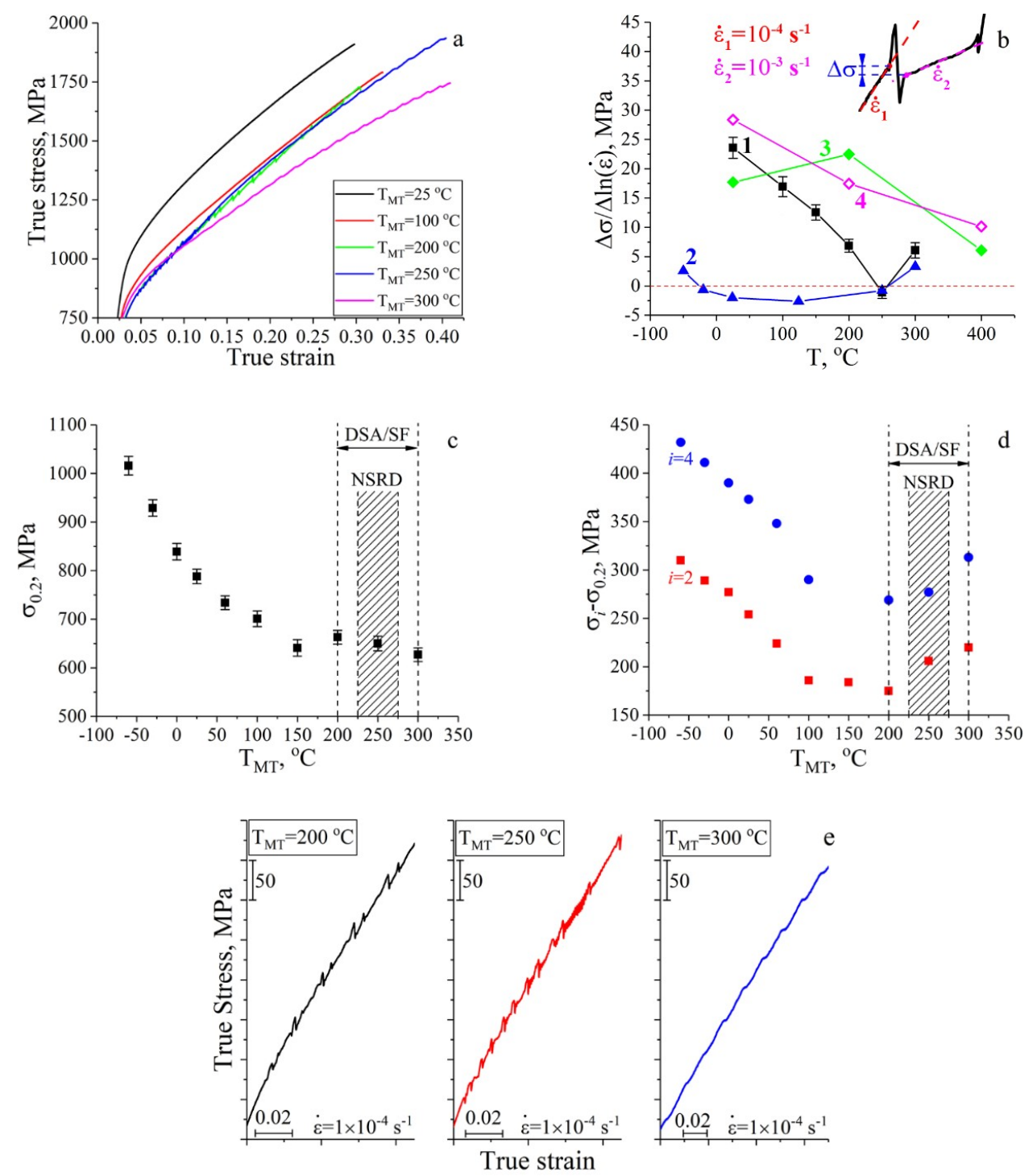

Figure 9. True stress vs. true strain diagrams for different $T_{M T}$ temperatures (a) and temperature dependences of the strain-rate sensitivity $\Delta \sigma / \Delta \ln (\dot{\varepsilon})(\mathbf{b})$, the yield strength (c) and strain-hardening $\sigma_{i}-\sigma_{0.2}(\mathbf{d})$ in UHIS, $\mathrm{T}_{\mathrm{SST}}=1200^{\circ} \mathrm{C}$. Magnified fragments of true stress vs. true strain diagrams for temperatures corresponded to the DSA regime are shown in (e). The insert in plot (b) shows the method of the estimation of $\Delta \sigma$-value, (1) corresponds to the UHIS specimens, (2) Fe-11.4Mn-1.13C [41], (3) Fe-19Cr-8Ni-0.5N [42], (4) Fe-22Cr-12Mn-1.0N [42]. DSA-dynamic strain aging, NSRD-negative strain-rate dependence, $\mathrm{SF}$-serrated flow.

According to Rodriguez [43] classification, an (A + B)-type serrations with the prevailing A-regime are observed in plastic flow diagrams corresponded to the temperature $200{ }^{\circ} \mathrm{C}$ (Figure 9e) (A-slip band unlocking, B-discontinuous band propagation due to the DSA of the moving dislocations within the bands [43]). This type of serrations starts at $2 \%$ of plastic deformation and lasts until specimens" failure. At $250^{\circ} \mathrm{C}$, the (A + B)-type with prevailing B-type regime is observed until $8 \%$ strain (Figure 9e) and a $\mathrm{C}$-type regime activates further (periodical dislocation unlocking). The $\mathrm{C}$-type serrations are characteristic of the plastic deformation of UHIS at $300{ }^{\circ} \mathrm{C}$ (Figure 9e). Flow instability, which is accompanied by serrations on stress-strain diagrams, is the temperature-dependent characteristic but it starts at low strains $\left(\varepsilon_{\mathrm{C}} \approx 1-2 \%\right.$ at $200-250{ }^{\circ} \mathrm{C}$ and $\varepsilon_{\mathrm{C}} \approx 6 \%$ at $\left.300{ }^{\circ} \mathrm{C}\right)$. 


\section{Discussion}

The steel demonstrates striking temperature dependence of the yield strength (Figure 4a) peculiar for $f c c$ alloys with high volume content of interstitials $[8,14,20,44,45]$. The $\sigma_{0.2}$-values in Figure 4 a show almost linear growth with the decrease in test temperature. Overall $\sigma_{0.2}\left(\mathrm{~T}_{\mathrm{MT}}\right)$-dependence in Figure $9 \mathrm{c}$ show that temperature interval $\left(-60\right.$ to $\left.+60{ }^{\circ} \mathrm{C}\right)$ lies in the thermally-activated part of this temperature dependence. Therefore, the linear interpolation could be applied. The slope of $\sigma_{0.2}\left(\mathrm{~T}_{\mathrm{MT}}\right)$-dependences in Figure $4 \mathrm{a}$ varies with the change in $\mathrm{T}_{\mathrm{SST}}$. The latter is obviously associated with the temperature dependence of the different strengthening components and with the change in their ratio. Assuming several basic components, the solid-solution hardening $\sigma_{\mathrm{SS}}$, particle strengthening $\sigma_{\mathrm{PS}}$ and grain size (Hall-Petch) strengthening $\sigma_{\mathrm{HP}}$, we have estimated their impact to the yield strength for room temperature deformation of UHIS in our previous research [39]. The increase in solid-solution temperature from $1100{ }^{\circ} \mathrm{C}$ up to $1230{ }^{\circ} \mathrm{C}$ is accompanied with concurrent hardening and softening effects. The solid-solution component (SSC) gives about 200-270 MPa hardening, basically due to increase in interstitial concentration. The increase in grain size (GSC, grain size component) and decrease in the volume fraction of precipitates (PSC, particle strengthening component) provide softening about $140 \mathrm{MPa}$ and $14 \mathrm{MPa}$ respectively [39]. In the percentage ratio, the contributions of these basic strengthening mechanisms are SSC/GSC/PSC $=35 \% / 60 \% / 5 \%$ for $\mathrm{T}_{\mathrm{SST}}=1100{ }^{\circ} \mathrm{C}$, SSC/GSC/PSC $=48 \% / 48 \% / 4 \%$ for $\mathrm{T}_{\mathrm{SST}}=1200{ }^{\circ} \mathrm{C}$ and SSC/GSC $/ \mathrm{PSC}=61 \% / 36 \% / 3 \%$ for $\mathrm{T}_{\mathrm{SST}}=1230{ }^{\circ} \mathrm{C}$ according to Reference [39]. The solid-solution hardening and grain size effect give high impact as compared to the minor effectiveness of the particle strengthening at room temperature and SSC contribution grows with increase in $\mathrm{T}_{\mathrm{SST}}$.

For nitrogen- and carbon-bearing austenitic steels, interstitial hardening is well-known and the most obvious temperature-dependent factor in the thermally-activated temperature range- $-\sigma_{\mathrm{SS}} \sim \sigma_{\mathrm{G}}+$ $\mathrm{U}_{0} / \mathrm{V}-\mathrm{AT} / \mathrm{V}\left(\mathrm{U}_{0}\right.$-activation energy at zero stress, $\mathrm{V}$-activation volume, A-constant which depends on the density of sites at which the activation occurs, Burgers vector of dislocations and the areas they swept during overcoming of the obstacles, strain rate and some other physical parameters) [8,12-14,20,45]. In this proportion, the athermal stress component $\sigma_{G}$ increases with growth of interstitial concentration and changes with the temperature proportionally to $G(T)$-dependence ( $G$ is a shear modulus). Activation volume $V$ decreases with increase in interstitial content. The variations in the austenite lattice parameter in UHIS testify to growth in solid-solution hardening with the increase in $\mathrm{T}_{\mathrm{SST}}$. As we reported in Reference [39] the total interstitial content (carbon and nitrogen) increases approximately 0.5 mass.\% due to increase in $\mathrm{T}_{\mathrm{SST}}$ from $1100^{\circ} \mathrm{C}$ up to $1230^{\circ} \mathrm{C}$. Consequently, the temperature-dependent increment of SSC in $\sigma_{0.2}\left(\mathrm{~T}_{\mathrm{MT}}\right)$-dependences increases with $\mathrm{T}_{\mathrm{SST}}$ and gives the most valuable contribution to the hardening of UHIS specimens after treatment at $\mathrm{T}_{\mathrm{SST}}=1230{ }^{\circ} \mathrm{C}$ (for clarification see scheme in Figure 10).
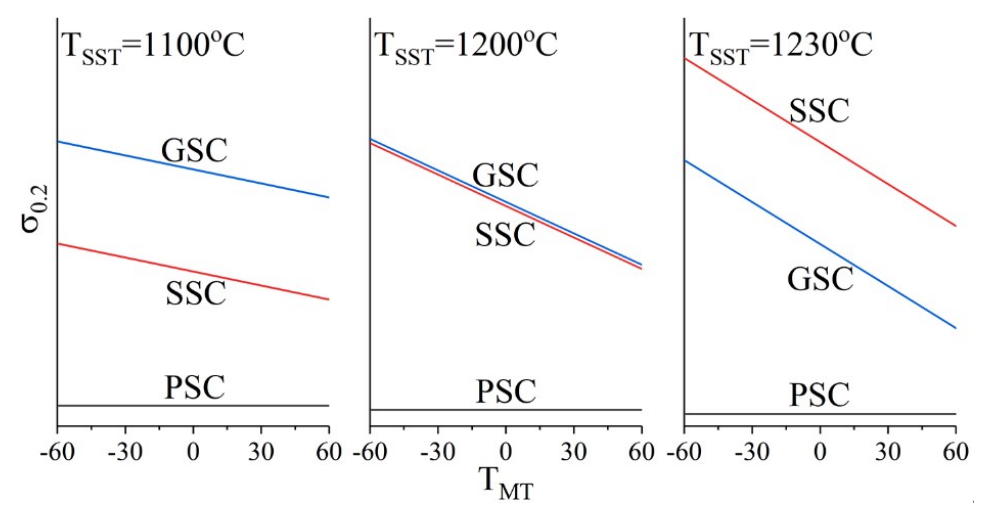

Figure 10. A scheme illustrating the change in temperature dependence of different strengthening components. GSC, SSC, PSC are grain size, solid-solution and particle strengthening components respectively. 
The temperature dependence of PSC for the UHIS is proportional to the temperature dependence of the shear modulus $\sigma_{\mathrm{PS}}(\mathrm{T}) \sim \mathrm{G}(\mathrm{T})$ [46]. The dominating deformation mechanism of the UHIS, dislocation slip, does not vary in chosen temperature range (Section 3.1, Figures 5-7). Therefore, the Burgers vector $b$ can be assumed as temperature-independent characteristic as well as particle size and volume fraction. Shear modulus increases with nitrogen-alloying but its temperature variation is about $5 \%$ in the temperature range from $+60{ }^{\circ} \mathrm{C}$ to $-60^{\circ} \mathrm{C}(\mathrm{G} \approx 79 \mathrm{GPa}$ and $\mathrm{G} \approx 83 \mathrm{GPa}$ respectively for $0.35 \mathrm{wt} . \%$ $\mathrm{N}$-bearing austenitic steel [47]). Assuming that PSC impact is just $3-5 \%$ of the overall strengthening of the steel in room temperature tests, the $\mathrm{G}(\mathrm{T})$-assisted low temperature hardening would be insufficient relative to other hardening components (SSC and GSC). This assumption does not consider the temperature-assisted change in dislocation arrangement and SFE of the UHIS. While planar dislocation arrays could increase PSC efficiency in low-temperature deformation regime but a splitting of $a / 2<110>$ perfect dislocation into two partials $a / 6<211>$ could, contrarily, reduce it (because $\sigma_{\mathrm{PS}}(\mathrm{T}) \sim \mathrm{b}, \mathrm{b}$ is the Burgers vector of dislocations). In view of low (3-4\%) overall contribution of particle strengthening in the yield strength of the UHIS, a temperature dependence of PSC has negligible effect in overall $\sigma_{0.2}\left(\mathrm{~T}_{\mathrm{MT}}\right)$-dependences in Figure $4 \mathrm{a}$ (Figure 10).

The grain size $\mathrm{d}$ is temperature-independent characteristic but the grain boundary hardening $\sigma_{\mathrm{HP}}(\mathrm{T}, \mathrm{C}) \sim \mathrm{k}_{\mathrm{HP}}(\mathrm{T}, \mathrm{C})(\mathrm{d})^{-1 / 2}$ is influenced by both temperature $\mathrm{T}_{\mathrm{MT}}$ and interstitial content $\mathrm{C}$ via proportionality coefficient $\mathrm{k}_{\mathrm{HP}}(\mathrm{T}, \mathrm{C})[8,12]$. P. Uggowitser and M. Harzenmoser [12] reported the increase in $\mathrm{k}_{\mathrm{HP}}$-value and the appearance of striking temperature dependence $\mathrm{k}_{\mathrm{HP}}(\mathrm{T})$ for high-nitrogen steel with $\mathrm{C}_{\mathrm{N}}>0.2$ mass.\%. They explained the increase in $\mathrm{k}_{\mathrm{HP}}(\mathrm{T}, \mathrm{C})$ at low temperatures by the remarkable change in substructure of the steels when planar dislocation arrays cause stronger grain boundary effect in comparison with a wavy glide. This approach agrees well with our experimental data about the dislocation arrangement in UHIS-the increase in TSST (interstitial content) and the decrease in test temperature both enhance planar slip. Therefore, the stronger temperature dependence $\sigma_{0.2}\left(\mathrm{~T}_{\mathrm{MT}}\right)$ for $\mathrm{T}_{\mathrm{SST}}=1230{ }^{\circ} \mathrm{C}$ in Figure $4 \mathrm{a}$ in comparison with two other SSTs is assisted by the increase in two dominating components - the solid-solution one and the grain-boundary one (scheme in Figure 10).

The transformation in dislocation substructure (increase in planarity of dislocation arrangement) of high-interstitial steels with increase in $\mathrm{T}_{\mathrm{SST}}$ could be governed by SFE, short-range ordering or clustering processes $[8,16,25,45,47]$. The UHIS specimens contain excess of $\mathrm{Cr}, \mathrm{Mn}, \mathrm{N}$ and $\mathrm{C}$ atoms and the growth in $\mathrm{T}_{\mathrm{SST}}$ increases the probability of nitrogen-chromium and/or manganese-carbon bonds. Therefore, the short-range atomic ordering could be assumed as one of the possible reason for formation of more powerful pile-ups (and softening of the slip planes) in specimens treated at $\mathrm{T}_{\mathrm{SST}}=1230{ }^{\circ} \mathrm{C}$ in comparison with those treated at $\mathrm{T}_{\mathrm{SST}}=1100{ }^{\circ} \mathrm{C}$ and $\mathrm{T}_{\mathrm{SST}}=1200{ }^{\circ} \mathrm{C}$ (Figures $5-7$ ). Direct measurement of the SFE (Table 1) also shows some decrease in SFE-value with increase in $\mathrm{T}_{\text {SST }}$. The measured values $25-50 \mathrm{~mJ} / \mathrm{mm}^{2}$ correspond to the interval of the SFEs when planar slip and twinning dominate but no deformation-induced phase transformations start [24]. The SFE-data in Table 1 do not follow the literature data of the other authors who testify to increase in SFE-value with increase in separate $\mathrm{N}$ or C-content in Cr-Mn austenitic steels $[8,24]$. But they satisfactory agree with data for complex $(\mathrm{C}+\mathrm{N})$-alloyed steels [13].

The gaining of the planar slip and intensification of mechanical twinning (see Section 3.1) in low-temperature tests correlate well with the experimentally confirmed decrease in SFE of the C- and $\mathrm{N}$-containing steels with decrease in test temperature [15,32]. The perfect dislocation dissociation width (splitting) varies according to $\left(\mathrm{G}(\mathrm{T})^{*} \mathrm{~b}(\mathrm{~T}) / \mathrm{SFE}(\mathrm{T})\right.$ )-relationship, where all three parameters are temperature-dependent variables. The shear modulus is inversely proportional to the temperature $\mathrm{T}$ and this could promote wavy glide. But two other $\mathrm{b}(\mathrm{T})$ and $\mathrm{SFE}(\mathrm{T})$ dependences assist dislocation splitting and favor planar slip. Twinning stress is directly proportional to the (SFE/ $\left.2 b_{p}\right)$-factor and it decreases in low-temperature deformation regime according to $\mathrm{SFE}(\mathrm{T})$ dependence $\left(\mathrm{b}_{\mathrm{p}}\right.$-Burgers vector of the partial $a / 6<211>$ dislocation). Both factors, a pile-up formation and mechanical twinning, are responsible for the gradual increase in contribution of the brittle cleavage-like component with decrease in test temperature described in Section 3.2. Despite this, the main fracture mechanism does 
not change in the chosen temperature range. And the dominating micromechanism of fracture in low-temperature tests is similar to those previously described for room-temperature deformation in UHIS [39] and low-temperature deformation of V-alloyed high-interstitial CrMn and CrMnNi steels with $C+N=(0.7-1.0)$ mass.\% [35]. Further evaluation of impact toughness is needed for characterization the DBT phenomenon and accurate measurements of the DBT temperature in the UHIS.

Another phenomenon, which should be discussed, is the dynamic strain aging observed in UHIS in the temperature interval $200-300{ }^{\circ} \mathrm{C}$ (Figure 9). This effect is usually ascribed to the interaction of mobile dislocations or stacking faults with solute atoms or their complexes. Its manifestations, the serrated flow, the negative strain-rate sensitivity and the increase in strain-hardening, are widely described in many research works. They basically concern the Fe-Mn-C alloying system assuming trapping of dislocations by C-atoms or Mn-C complexes [32,43,45,48]. Limited data exist about the appearance of DSA in nitrogen-alloyed austenitic steels, whilst it is pronounced in Fe-Mn-C steels. The comparison of the temperature dependences of the strain-rate sensitivity for some steels with different concentrations of carbon and nitrogen in Figure $9 \mathrm{~b}$ shows that pure nitrogen-bearing steels do not usually manifest DSA phenomenon at temperatures lower than $300{ }^{\circ} \mathrm{C}$ [42]. V. Ganesan et al. [49] pointed out that, for type 316LN steel, the increase in N-content (up to 0.22 mass.\%) shifted the onset of DSA appearance to the higher temperature and strains. H.K. Yang et al. [33] reported that $\mathrm{N}$ additions delayed the critical strain for DSA and suppressed the appearance of the Porteven-le Chatelier bands in TWIP Fe-23Mn-0.6C-0.1N steel. We have found the only work of P. Uggowitzer and M. Harzenmoser [12] who show the appearance of the serrated flow in $0.55 \mathrm{~N}-0.06 \mathrm{C}-18 \mathrm{Cr}-19 \mathrm{Mn}-0.05 \mathrm{Mo}-0.36 \mathrm{Si}$ steel at rather low temperature $\mathrm{T}>250^{\circ} \mathrm{C}$ and strain rate $10^{-4} \mathrm{~s}^{-1}$. This could be partially assisted by low carbon additions in steel composition. Despite the negative strain-rate sensitivity interval is narrow and lies about $250{ }^{\circ} \mathrm{C}$ for UHIS, the serrations of the stress-strain diagrams are clearly visible at $200{ }^{\circ} \mathrm{C}$ and the plateau on $\sigma_{0.2}\left(\mathrm{~T}_{\mathrm{MT}}\right)$-dependence starts at $200{ }^{\circ} \mathrm{C}$ (Figure 9). Therefore, the DSA interval started at the temperature of about $200{ }^{\circ} \mathrm{C}$ for the UHIS steel. This temperature is distinctly lower than most mentioned above data for nitrogen-bearing steels (Figure 9b). The composition of the UHIS steel contains high concentrations of Mn and C atoms similar to typical TWIP steels (13-30 mass.\% of $\mathrm{Mn}$ and $0.3-0.8$ mass.\% of C). Taking it into account, the appearance of the DSA phenomenon at the temperatures $200-300{ }^{\circ} \mathrm{C}$ could be ascribed to the interaction of $\mathrm{Mn}$ and $\mathrm{C}$ atoms with mobile dislocations. But the direct comparison of the DSA temperature interval for the UHIS and typical Fe-Mn-C TWIP-steel (Hadfield steel) with pronounced DSA in Figure 9b showed that complex alloying of steels with nitrogen and carbon shifted DSA interval to the higher temperatures.

\section{Conclusions}

This study reports the tensile mechanical properties, microstructure and fracture micromechanisms of the ultrahigh-interstitial austenitic Fe-22Cr-26Mn-1.3V-0.7C-1.2N steel with $\mathrm{C}+\mathrm{N}=1.9$ mass. $\%$ $(\mathrm{C} / \mathrm{N}=0.6)$ in the range of testing temperatures from $-60{ }^{\circ} \mathrm{C}$ to $300{ }^{\circ} \mathrm{C}$.

(1) In the temperature interval of -60 to $+60^{\circ} \mathrm{C}$, the steel demonstrates the striking temperature dependence of the yield strength which could be enhanced by the increase in solid-solution treatment temperature. The stronger temperature dependence $\sigma_{0.2}\left(\mathrm{~T}_{\mathrm{MT}}\right)$ for specimens treated at $\mathrm{T}_{\mathrm{SST}}=1230{ }^{\circ} \mathrm{C}$ in comparison with $\mathrm{T}_{\mathrm{SST}}=1100^{\circ} \mathrm{C}$ and $\mathrm{T}_{\mathrm{SST}}=1200^{\circ} \mathrm{C}$ is provided by two dominating temperature-dependent components, the solid-solution one and the grain-boundary one. But the contribution from dispersion hardening is negligible in whole temperature range.

(2) Independently on SST temperature, dislocation slip is the main deformation mechanism of the steel in test temperature interval -60 to $+60{ }^{\circ} \mathrm{C}$. Lower deformation temperature and higher solid-solution treatment temperature force the planar dislocation arrangement and gain the mechanical twinning. Increase in slip planarity and twinning activity is accompanied with slight increase of brittle cleavage-like component on fracture surfaces of the steel specimens. Nevertheless, for studied solid-solution temperatures and test temperatures, the steel does not demonstrate the ductile-to-brittle transition in tension. As the given temperature range -60 to $+60{ }^{\circ} \mathrm{C}$ corresponds to the common climatic 
temperature range for constructional materials, the ultrahigh-interstitial steel could be assumed as the perspective high-strength ductile material with reasonable plastic properties.

(3) After solid-solution treatment at temperature of $1200{ }^{\circ} \mathrm{C}$ (with low content of grain-boundary precipitates and high solid-solution hardening) the steel demonstrates the attributes of the dynamic strain aging phenomenon. The complex alloying of the steel with nitrogen and carbon shifted the DSA temperature interval to the higher temperatures as compared to carbon-bearing steels.

Author Contributions: Conceptualization, E.A. and N.G.; investigation, S.A., V.M., M.P., G.M., E.M., K.R., I.T.; Methodology, S.A.; supervision, E.A.; writing-original draft, S.A.; writing-review and editing, E.A. All authors have read and agreed to the published version of the manuscript.

Funding: The reported research was funded by Russian Foundation for Basic Research and the government of the Tomsk region of the Russian Federation (project No. 18-48-700042). The studies were conducted using the equipment of the Institute of Strength Physics and Materials Science ("Nanotech" center).

Conflicts of Interest: The authors declare no conflict of interest.

\section{References}

1. Lo, K.H.; Shek, C.H.; Lai, J.K.L. Recent developments in stainless steels. Mater. Sci. Eng. R. 2009, 65, 39-104. [CrossRef]

2. Bhadeshia, H.K.D.H.; Honeykombe, R.W.K. Steels: Microstructure and Properties; Elsevier: Amsterdam, The Netherlands, 2006.

3. Rajasekhara, S.; Ferreira, P.J.; Karjalainen, L.P.; Kyrolainen, A. Hall-Petch behavior in ultra-fine-grained AISI 301LN stainless steel. Metallurg. Mater. Trans. A 2007, 38A, 1202-1210. [CrossRef]

4. Yanushkevich, Z.; Lugovskaya, A.; Belyakov, A.; Kaibyshev, R. Deformation microstructures and tensile properties of an austenitic stainless steel subjected to multiple warm rolling. Mater. Sci. Eng. A 2016, 667, 279-285. [CrossRef]

5. Astafurova, E.G.; Melnikov, E.V.; Astafurov, S.V.; Ratochka, I.V.; Mishin, I.P.; Maier, G.G.; Moskvina, V.A.; Zakharov, G.N.; Smirnov, A.I.; Bataev, V.A. Hydrogen embrittlement effects on austenitic stainless steels with ultrafine-grained structure of different morphology. Phys. Mesomech. 2019, 22, 313-326. [CrossRef]

6. Astafurov, S.V.; Maier, G.G.; Melnikov, E.V.; Moskvina, V.A.; Panchenko, M.Y.; Astafurova, E.G. The strain-rate dependence of the Hall-Petch effect in two austenitic stainless steels with different stacking fault energies. Mater. Sci. Eng. A 2019, 756, 365-372. [CrossRef]

7. Karavaeva, M.V.; Abramova, M.M.; Enikeev, N.A.; Raab, G.I.; Valiev, R.Z. Superior strength of austenitic steel produced by combined processing, including equal-channel angular pressing and rolling. Metals 2016, 6, 310. [CrossRef]

8. Gavriljuk, V.G.; Berns, H. High Nitrogen Steels; Springer: Berlin, Germany, 1999.

9. Reed, R.P. Nitrogen in austenitic stainless steels. JOM 1989, 41, 16-21. [CrossRef]

10. Stein, G.; Menzel, J.; Dörr, H. Industrial manufacture of massively nitrogen-alloyed steels. In High Nitrogen Steels, HNS-88; Foct, J., Hendry, A., Eds.; The Institute of Metals: London, UK, 1989; pp. 32-38.

11. Pickering, F.B. Some beneficial effects of nitrogen in steel. In High Nitrogen Steels, HNS-88; Foct, J., Hendry, A., Eds.; The Institute of Metals: London, UK, 1989; pp. 10-31.

12. Uggowitzer, P.J.; Harzenmozer, M. Strengthening of austenitic stainless steels by nitrogen. In High Nitrogen Steels, HNS-88; Foct, J., Hendry, A., Eds.; The Institute of Metals: London, UK, 1989; pp. 174-179.

13. Berns, H.; Gavriljuk, V.; Riedner, S. High Interstitial Stainless Austenitic Steels; Springer: Berlin/Heidelberg, Germany, 2013.

14. Rawers, J.; Grujicic, M. Effect of metal composition and temperature on the yield strength of nitrogen strengthened stainless steels. Mater. Sci. Eng. A 1996, 207, 188-194. [CrossRef]

15. Gavriljuk, V.G.; Sozinov, A.L.; Foct, J.; Petrov, J.N.; Polushkin, Y.A. Effect of nitrogen on the temperature dependence of the yield strength of austenitic steels. Acta Mater. 1998, 46, 1157-1163. [CrossRef]

16. Mullner, P.; Solenthaler, C.; Uggowitzer, P.J.; Spidel, M.O. Brittle fracture in austenitic steel. Acta Mater. 1994, 42, 2211-2217. [CrossRef]

17. Tomota, Y.; Xia, Y.; Inoue, K. Mechanism of low temperature brittle fracture in high nitrogen bearing austenitic steels. Acta Mater. 1998, 46, 1577-1587. [CrossRef] 
18. Tobler, R.L.; Meyn, D. Cleavage-like fracture along slip planes in Fe-18Cr-3Ni-13Mn-0.37N austenitic stainless steel at liquid helium temperature. Metallurg. Trans. A 1988, 19A, 1626-1631. [CrossRef]

19. Liu, S.; Liu, D.; Liu, S. Transgranular fracture in low temperature brittle fracture of high nitrogen austenitic steel. J. Mater. Sci. 2007, 42, 7514-7519. [CrossRef]

20. Chumlyakov, Y.I.; Kireeva, I.V.; Sehitoglu, H.; Litvinova, E.I.; Zaharova, E.G.; Luzginova, N.V. High-strength single crystals of austenitic stainless steel with nitrogen content: Mechanisms of deformation and fracture. Mater. Sci. Forum. 1999, 318-320, 395-400. [CrossRef]

21. Hwang, B.; Lee, T.-H.; Kim, S.-J. Effects of deformation-induced martensite and grain size on ductile-to-brittle transition of austenitic 18Cr-10Mn-N stainless steels. Met. Mater. Int. 2010, 16, 905-911. [CrossRef]

22. Hwang, B.; Lee, T.-H.; Park, S.-J.; Oh, C.-S.; Kim, S.-J. Correlation of austenite stability and ductile-to-brittle transition behavior of high-nitrogen 18Cr-10Mn austenitic steels. Mater. Sci. Eng. A 2011, 528, 7257-7266. [CrossRef]

23. Kireeva, I.V.; Chumlyakov, Y.I. Effect of nitrogen and stacking-fault energy on twinning in [111] single crystals of austenitic stainless steels. Phys. Met. Metallogr. 2009, 108, 298-309. [CrossRef]

24. Mosecker, L.; Saeed-Akbari, A. Nitrogen in chromium-manganese stainless steels: A review on the evaluation of stacking fault energy by computational thermodynamics. Sci. Tech. Adv. Mater. 2013, 14, 033001. [CrossRef]

25. Mullner, P.; Solenthaler, C.; Uggowitzer, P.; Speidel, M.O. On the effect of nitrogen on the dislocation structure of austenitic stainless steel. Mater. Sci. Eng. A 1993, 164, 164-169. [CrossRef]

26. Panin, V.E.; Derevyagina, L.S.; Panin, S.V.; Shugurov, A.R.; Gordienko, A.I. The role of nanoscale strain-induced defects in the sharp increase of low-temperature toughness in low-carbon and low-alloy steels. Mater. Sci. Eng. A 2019, 768, 138491. [CrossRef]

27. Akbari, A.; Mohammadzadeh, R. Effect of grain refinement on the mechanical properties of a nickel- and manganese-free high nitrogen austenitic stainless steel. Metallurg. Mater. Trans. A 2015, 46A, 1570-1579. [CrossRef]

28. Gavriljuk, V.G.; Shanina, B.D.; Berns, H. A physical concept for alloying steels with carbon + nitrogen. Mater. Sci. Eng. A 2008, 481-482, 707-712. [CrossRef]

29. Shanina, B.; Gavriljuk, V.; Berns, H.; Schmalt, F. Concept of a new high-strength low-cost stainless steel. Steel Res. 2002, 73, 105-113. [CrossRef]

30. Gavriljuk, V.G.; Shanina, B.D.; Berns, H. Ab initio development of a high-strength corrosion resistant austenitic steel. Acta Mater. 2008, 56, 5071-5082. [CrossRef]

31. Berns, H.; Nabiran, N.; Mujica, L. High-interstitial stainless austenitic steel castings. Steel Res. Int. 2013, 84, 119-128. [CrossRef]

32. Mosecker, L.; Pierce, D.T.; Schwedt, A.; Beighmohamadi, M.; Mayer, J.; Bleck, W.; Wittig, J.E. Temperature effect on deformation mechanisms and mechanical properties of a high manganese $\mathrm{C}+\mathrm{N}$ alloyed austenitic stainless steel. Mater. Sci. Eng. A 2015, 642, 71-83. [CrossRef]

33. Yang, H.K.; Tian, Y.Z.; Zhang, Z.J.; Zhang, Z.F. Simultaneously improving the strength and ductility of Fe-22Mn-0.6C twinning-induced plasticity steel via nitrogen addition. Mater. Sci. Eng. A 2018, 715, 276-280. [CrossRef]

34. Saenarjhan, N.; Kang, J.-H.; Kim, S.-J. Effect of carbon and nitrogen on austenite stability and tensile deformation behavior of $15 \mathrm{Cr}-15 \mathrm{Mn}-4 \mathrm{Ni}$ based austenitic stainless steels. Mater. Sci. Eng. A 2019, 742, 608-616. [CrossRef]

35. Astafurova, E.G.; Moskvina, V.A.; Maier, G.G.; Gordienko, A.I.; Burlachenko, A.G.; Smirnov, A.I.; Bataev, V.A.; Galchenko, N.K.; Astafurov, S.V. Low-temperature tensile ductility by V-alloying of high-nitrogen CrMn and CrNiMn steels: Characterization of deformation microstructure and fracture micromechanisms. Mater. Sci. Eng. A 2019, 745, 265-278. [CrossRef]

36. Astafurova, E.; Moskvina, V.; Maier, G.; Melnikov, E.; Galchenko, N.; Astafurov, S.; Gordienko, A.; Burlachenko, A.; Smirnov, A.; Bataev, V. The effect of test temperature on deformation microstructure and fracture mechanisms in CrMn high-nitrogen steels alloyed (0-3 wt.\%) with vanadium. Mater. Sci. Forum. 2018, 941, 27-32. [CrossRef]

37. Bannykh, O.A.; Blinov, V.M. On the effect of discontinuous decomposition on the structure and properties of high-nitrogen steels and on methods for suppression thereof. Steel Res. 1991, 62, 38-45. [CrossRef] 
38. Blinov, V.M. Progress in the study of high-nitrogen corrosion-resistant aging nonmagnetic vanadium steels. Russ. Metall. (Metally) 2007, 2, 127-135. [CrossRef]

39. Astafurov, S.V.; Maier, G.G.; Tumbusova, I.A.; Melnikov, E.V.; Moskvina, V.A.; Panchenko, M.Y.; Smirnov, A.I.; Galchenko, N.K.; Astafurova, E.G. The effect of solid-solution temperature on phase composition, tensile characteristics and fracture mechanism of V-containing CrMn-steels with high interstitial content $\mathrm{C}+\mathrm{N}>1$ mass. \%. Mater. Sci. Eng. A 2020, 770, 138534. [CrossRef]

40. Hirsch, P.B.; Howie, A.; Nicholson, R.B.; Pashley, D.W.; Whelan, M.J. Electron Microscopy of Thin Crystals; Butterworths: London, UK, 1965.

41. Dastur, Y.N.; Leslie, W.C. Mechanism of work hardening in Hadfield manganese steel. Metallurg. Trans. A 1981, 12, 749-759. [CrossRef]

42. Ilola, R.; Kemppainen, M.; Hanninen, H. Dynamic strain aging of austenitic high-nitrogen Cr-Ni and Cr-Mn steels. Mater. Sci. Forum. 1999, 318-320, 407-412. [CrossRef]

43. Rodriguez, P. Serrated plastic flow. Bull. Mater. Sci. 1984, 6, 653-663. [CrossRef]

44. Tanaka, M.; Onomoto, T.; Tsuchiyama, T.; Higashida, K. Brittle-to-ductile transition in nickel-free austenitic stainless steels with high nitrogen. ISIJ Int. 2012, 52, 915-921. [CrossRef]

45. Bouaziz, O.; Allain, S.; Scott, C.P.; Cugy, P.; Barbier, D. High manganese austenitic twinning induced plasticity steels. A review of the microstructure properties relationship. Curr. Opin. Solid State Mater. Sci. 2011, 15, 141-168. [CrossRef]

46. Gladman, T. Precipitation hardening in metals. Mater. Sci. Technol. 1999, 15, 30-36. [CrossRef]

47. Byrnes, M.L.G.; Grujicic, M.; Owen, W.S. Nitrogen strengthening of a stable austenitic stainless steel. Acta Metallurg. 1987, 35, 1853-1862. [CrossRef]

48. Lee, S.-J.; Kim, J.; Kane, S.N.; De Cooman, B.C. On the origin of dynamic strain aging in twinning-induced plasticity steels. Acta Mater. 2011, 59, 6809-6819. [CrossRef]

49. Ganesan, V.; Laha, K.; Nandagopal, M.; Parameswaran, P.; Mathew, M.D. Effect of nitrogen content on dynamic strain ageing behaviour of type 316LN austenitic stainless steel during tensile deformation. Mater. High. Temp. 2014, 31, 162-170. [CrossRef]

(C) 2020 by the authors. Licensee MDPI, Basel, Switzerland. This article is an open access article distributed under the terms and conditions of the Creative Commons Attribution (CC BY) license (http://creativecommons.org/licenses/by/4.0/). 